\title{
Antiangiogenic agents in advanced gastrointestinal malignancies: past, present and a novel future
}

\section{Karen Mulder, Sheryl Koski, Andrew Scarfe, Quincy Chu, Karen King, Jennifer Spratlin}

\author{
*Medical Oncology, Cross Cancer Institute, University of Alberta, Alberta, Canada, \\ Correspondence to: Jennifer Spratlin, e-mail: jennifer.spratlin@albertahealthservices.ca
}

Keywords: angiogenesis, anti-angiogenic agents, Bevacizumab, sorafenib, gastrointestinal cancers, biomarkers

Received: August 30, 2010,

Accepted: October 15, 2010,

Published: October 15, 2010

Copyright: ( ) Mulder et al. This is an open-access article distributed under the terms of the Creative Commons Attribution License, which permits unrestricted use, distribution, and reproduction in any medium, provided the original author and source are credited.

ABSTRACT:

\begin{abstract}
Advanced gastrointestinal (GI) malignancies are varied in presentation, prognosis, and treatment options. With the exception of resectable recurrent colorectal cancer, metastatic GI malignancies are incurable. Cytotoxic chemotherapies have been the mainstay of therapy for decades but limited extension of survival or clinical benefit has been achieved in non-colorectal GI cancers. There has been great interest in the incorporation of antiangiogenic strategies to improve outcomes for these patients. Clear benefits have been identified with bevacizumab and sorafenib in colorectal cancer and hepatocellular cancer, respectively; other GI tumor sites have lacked impressive results with antiangiogenic agents. In this review, we will present the benefits, or lack thereof, of clinically tested antiangiogenic compounds in GI malignancies and explore some potential new therapeutic anti-angiogenesis options for these diseases.
\end{abstract}

\section{INTRODUCTION}

Up-regulation of angiogenesis is required for development of malignancy, tumor growth and progression [1,2]. The vascular endothelial growth factor family of ligands (VEGF-A (VEGF), VEGF-B, VEGF-C, VEGF-D, VEGF-E, and placental growth factor(PlGF)) and receptors (VEGFR-1, VEGFR-2, VEGFR-3, FLT-3, platelet derived growth factor receptor (PDGFR), and C-KIT) are the most studied angiogenic pathways $[3,4]$. (FIGURE 1) Extracellular interaction of the ligands with VEGFRs encourages receptor dimerization, leads to receptor autophosphorylation, and subsequently activates downstream angiogenic and growth pathways. VEGF binds primarily to VEGFR-1 and VEGFR-2 whose expression is more pronounced in tumor vasculature endothelial cells [5]. VEGF/VEGFR binding results in cellular proliferation, vascular differentiation, altered vascular permeability, and migration [6-13].

Inhibiting cellular angiogenic machinery is a well researched area of cancer care. Over the last decade, several antiangiogenic compounds have been developed, investigated, and approved for cancer treatment. Inhibiting angiogenesis can occur via various mechanisms. To date, drug development has focused on blocking this pathway via inhibition of the ligand (VEGF), the receptors (VEGFRs), and the effector intracellular tyrosine kinase pathways. (TABLE 1) When the addition of bevacizumab, a monoclonal antibody ( $\mathrm{mAb}$ ) inhibiting VEGF, to chemotherapy for advanced colorectal cancer (CRC) offered an almost 5 month survival benefit, considerable effort was directed to develop other angiogenesis blockers[14]. Subsequent studies have attempted to match this benefit in other tumor types.

Advanced gastrointestinal (GI) malignancies are a wide spectrum of diseases with variable prognoses depending on the stage at diagnosis. On one end of this spectrum is advanced gastric and pancreatic cancers which have uniformly poor overall survival from diagnosis regardless of treatment; on the other end of this spectrum is metastatic CRC which, when treated with a sequence of well established therapies, affords a median survival in excess of two years. The use of biologic agents, particularly antiangiogenics, has been at the forefront of clinical investigations in GI malignancies for most of the last decade. Mechanistically, the theories behind inhibiting new blood vessel formation, including improved delivery of concurrently administered cytotoxic drugs and promotion of effective delivery of blood and nutrients intra-tumorally, are valid. Unfortunately, for 
uncertain reasons, many antiangiogenic agents have not been effective in GI cancers. Herein, we review the use of antiangiogenic compounds which have proven clinical benefit in GI malignancies, discuss some novel agents currently under investigation, and make critical conclusions as to the effectiveness of this avenue as anticancer treatment in GI tumors

\section{ESOPHAGOGASTRIC CANCERS (EGC)}

Gastric and esophageal cancers are the second and sixth leading causes of cancer related death worldwide, respectively [15]. Esophageal adenocarcinoma is now more prevalent than squamous cell carcinoma in North America and Western Europe and, as it is often difficult to determine if the cancer originates in the gastroesophageal junction or distal esophagus, patients with advanced diseases are often treated akin to advanced gastric adenocarcinoma. There is little data on the role of angiogenesis inhibitors in patients with esophageal squamous cell carcinoma. As such, this discussion will be limited to EGC adenocarcinoma.

Patients with metastatic EGC have 5 year survival rates of $10-15 \%$. When compared to best supportive care, palliative cytotoxic chemotherapy improves survival [16-18]. Although there is no single internationally accepted standard of care regimen, the best survival rates are achieved with three drug combinations compared to doublet therapy [19].

VEGF and angiogenesis appear to have an important role in pathogenesis and prognosis of EGC. VEGF expression increases with increasing stage and disease burden in EGC [20,21]. Furthermore, VEGF expression is a negative prognostic factor for survival in this patient group [22,23]. In a gastric xenograft model, inhibition of VEGF activity by an immuno-neutralizing antibody was effective suggesting that VEGF inhibition may have therapeutic value [24]. Phase II studies of bevacizumab combined with chemotherapy (irinotecan and cisplatin; oxaliplatin and docetaxel or 5-fluoruracil (FU); docetaxel, cisplatin, and FU) showed promising results in previously treated and untreated patients (RR 63-71\%) [25-28]. The phase III study, AVAGAST, which combined bevacizumab or placebo with capecitabine and cisplatin showed a significant improvement in overall response rate (ORR $38 \%$ vs $29.5 \%$ ) and progression free survival (PFS 6.7 vs 5.3 months) [29]. However, the study failed to improve overall survival (OS), its primary endpoint.

Ramucirumab, a monoclonal antibody directed at VEGFR-2, is currently being tested in a randomized phase III study as a second-line agent in metastatic EGC (NCT009117384).

Several small molecule TKIs to VEGFRs have also undergone early phase II testing in EGC. Sorafenib in

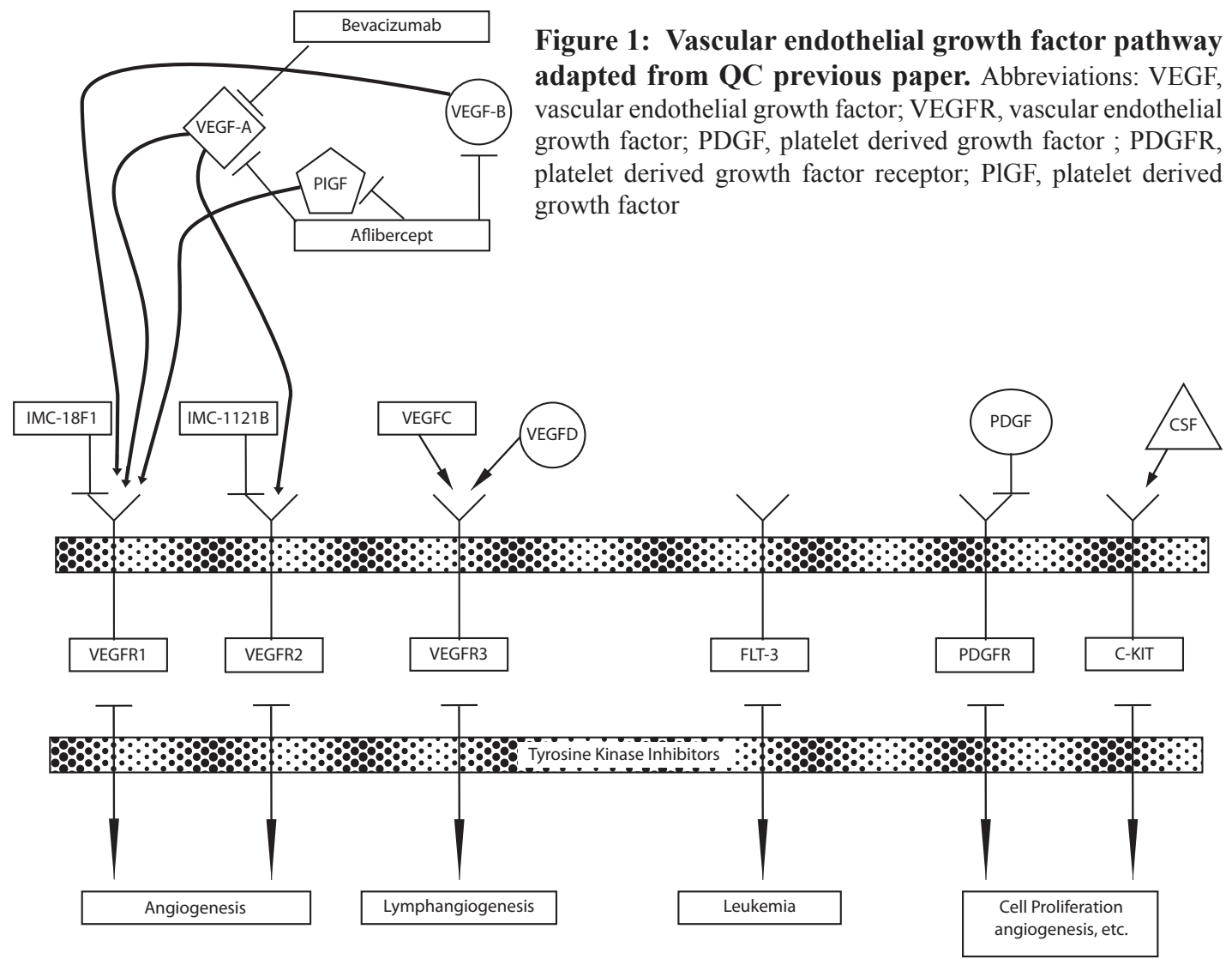




\begin{tabular}{|c|c|c|c|}
\hline $\begin{array}{l}\text { Anti- } \\
\text { angiogenic } \\
\text { agent }\end{array}$ & $\begin{array}{l}\text { Mechanism of } \\
\text { Action }\end{array}$ & $\begin{array}{c}\text { Tumour Sites } \\
\text { of Interest }\end{array}$ & Toxicities from dose finding studies \\
\hline Bevacizumab & $\begin{array}{l}\text { IV recombinant } \\
\text { humanized } \\
\text { monoclonal antibody } \\
\text { against VEGF }\end{array}$ & $\mathrm{CRC}$ & $\begin{array}{l}\text { Anemia, dyspnea, intracranial bleed, tumor } \\
\text { hemorrhage }\end{array}$ \\
\hline Sunitinib & $\begin{array}{l}\text { Oral multitargeted } \\
\text { TKI inhibiting } \\
\text { VEGFR-1, VEGFR-2, } \\
\text { PDGFR- } \beta \text {, c-KIT, } \\
\text { FLT3, and RET }\end{array}$ & $\mathrm{HBC}$ & $\begin{array}{l}\text { Fatigue, HTN, bullous skin toxicity, elevated } \\
\text { lipase/amylase, decrease LVEF, edema, } \\
\text { thrombocytopenia, tumor necrosis, asthenia, } \\
\text { nausea, vomiting, HTN, PE, phlebitis, } \\
\text { neutropenia, thrombocytopenia, skin toxicity, } \\
\text { tumor related fistulas, anemia }\end{array}$ \\
\hline Sorafenib & $\begin{array}{l}\text { Oral multitargeted } \\
\text { TKI inhibiting } \\
\text { VEGFR-1, VEGFR-2, } \\
\text { PDGFR- } \beta \text {, Raf-1, B- } \\
\text { Raf, and intracellular } \\
\text { serine-threonine } \\
\text { kinases }\end{array}$ & $\mathrm{HBC}$ & $\begin{array}{l}\text { Rash, HTN, dyspnea, fatigue, HFS, abdominal } \\
\text { cramping, diarrhea, retrosternal pain, edema of } \\
\text { uvula, anorexia, fatigue, anorexia, diarrhea, } \\
\text { rash/desquamation, HFS, nausea, alopecia }\end{array}$ \\
\hline Cediranib & $\begin{array}{l}\text { Oral TKI to VEGFR- } \\
\text { 1, VEGFR-2, } \\
\text { VEGFR-3 }\end{array}$ & $\begin{array}{l}\text { Gastric } \\
\text { CRC }\end{array}$ & $\begin{array}{l}\text { Hypertension, hypertensive crisis, } \\
\text { hypoglycemia, elevated bilirubin, fatigue, } \\
\text { diarrhea, nausea, dysphonia, hypertension, } \\
\text { vomiting, anorexia }\end{array}$ \\
\hline Valatinib & $\begin{array}{l}\text { Oral TKI to VEGFR- } \\
1, \text { VEGFR-2, } \\
\text { VEGFR-3, PDGFR, } \\
\text { c-kit }\end{array}$ & CRC & $\begin{array}{l}\text { Lightheadedness, fatigue, vomiting, nausea, } \\
\text { diarrhea, HTN }\end{array}$ \\
\hline Brivanib & $\begin{array}{l}\text { Oral TKI to VEGFR- } \\
2 \text { and FGFR-1 }\end{array}$ & CRC & $\begin{array}{l}\text { HTN, fatigue, AST/ALT elevation, thyroid } \\
\text { dysfunction, hyponatremia }\end{array}$ \\
\hline ZD6474 & $\begin{array}{l}\text { Oral TKI to VEGFR- } \\
\text { 2, RET, Flt-4, } \\
\text { VEGFR-3, EGFR }\end{array}$ & pancreas & $\begin{array}{l}\text { Diarrhea, HTN, rash, folliculitis, } \\
\text { hypophosphatemia, increased ALT, bowel } \\
\text { obstruction, colitis, fatigue, thrombocytopenia, } \\
\text { rash, nausea, HTN, fatigue, anorexia, CHF, PE, } \\
\text { DVT, bowel ischemia }\end{array}$ \\
\hline ABT-869 & $\begin{array}{l}\text { Oral TKI to VEGFR- } \\
1, \text { VEGFR-2, } \\
\text { VEGFR-3, PDGFRß, } \\
\text { and Flt3 }\end{array}$ & $\begin{array}{l}\mathrm{CRC} \\
\mathrm{HCC}\end{array}$ & $\begin{array}{l}\text { Fatigue, proteinuria, HTN, asthenia, HFS, } \\
\text { myalgia }\end{array}$ \\
\hline Ramucirumab & $\begin{array}{l}\text { IV anti-VEGFR2 } \\
\mathrm{mAB}\end{array}$ & $\mathrm{CRC}$ & $\begin{array}{l}\text { HTN, DVT, headache, proteinuria, vomiting, } \\
\text { amylasemia }\end{array}$ \\
\hline IMC-18F1 & $\begin{array}{l}\text { IV anti-VEGFR1 } \\
\mathrm{mAB}\end{array}$ & CRC & Fatigue, nausea, anemia \\
\hline Aflibercept & $\begin{array}{l}\text { VEGF-A, VEGF-B, } \\
\text { PIGF fully human } \\
\text { recombinant decoy } \\
\text { fusion protein }\end{array}$ & $\begin{array}{l}\text { gastric } \\
\text { pancreas } \\
\text { CRC }\end{array}$ & Rectal ulceration, proteinuria, HTN \\
\hline
\end{tabular}

Table 1: Comparison of anti-angiogenic agents. Abbreviations: VEGF, vascular endothelial growth factor; VEGFR, vascular endothelial growth factor; PDGF, platelet derived growth factor ; PDGFR, platelet derived growth factor receptor; PlGF, platelet derived growth factor; CRC, colorectal cancer; HBC, hepatobiliary cancers; HTN, hypertension; DVT, deep venous thrombosis; CHF, congestive heart failure; PE, pulmonary embolism; ALT, alanine transferase; HFS, hand-foot syndrome; LVEF, left ventricular ejection fraction 
combination with docetaxel and cisplatin in treatmentnaive patients with metastatic EGC demonstrated partial responses (PR) of $41 \%$, median PFS of 5.8 months, and median OS of 13.6 months [30]. Sunitinib as a secondline single agent treatment for advanced gastric cancer demonstrated a disease control rate of $35 \%$ [31].

\section{CANCERS OF THE HEPATOBILIARY TRACT}

\section{Hepatocellular Carcinoma (HCC)}

HCC is the third leading cause of death worldwide after lung and gastric cancer [32]. Less than 30\% of patients are eligible for surgery due to advanced stage of disease at presentation and treatment with cytotoxic chemotherapy has been disappointing with multiple studies failing to show an improvement in OS [33]. HCC's are highly vascular tumors. High microvessel density and levels of circulating VEGF are associated with poorer outcomes, thus making the angiogenesis pathway an attractive therapeutic target [34-39].

Sorafenib is the first systemic agent demonstrating an improvement in OS in patients with advanced HCC. The initial phase II study of 137 patients showed promising activity with a median OS of 9.2 months and a median time to progression (TTP) of 5.5 months [40]. Patients with Child-Pugh Class B liver function had similar incidence of drug-related adverse events but had more frequent worsening of liver disease (encephalopathy $11 \%$ vs. $2 \%$; worsening ascites $18 \%$ vs. $11 \%$ ) than patients with Child-Pugh A liver function as well as significantly worse OS (14 weeks vs. 41 weeks) [41]. Two phase III, multicenter, randomized, placebo-controlled studies confirmed the activity of this agent. Both studies limited enrollment to patients with Childs-Pugh A liver function. The SHARP study enrolled patients from Europe, North and South America and Australasia and had hepatitis $\mathrm{C}$ and alcohol as the predominant risk factors for HCC. The Asia-Pacific trial enrolled patients from China, South Korea and Taiwan and had hepatitis B as the predominant HCC risk factor. Both studies demonstrated a significant OS improvement (SHARP: 10.7 vs. 7.9 months, HR $0.69, \mathrm{p}<0.001$; Asia-Pacific: 6.5 vs. 4.2 months, HR 0.68, $\mathrm{p}=0.014$ ) and disease control rate (SHARP: $43 \%$ vs. $32 \%$, $\mathrm{p}=0.0002$; Asia-Pacific: $35.5 \%$ vs. $15.8 \%, \mathrm{p}=0.0019)$ with sorafenib as compared to best supportive care. Response rates (RR) were low (2\% and $3.3 \%$ respectively) and there was no difference between the arms in time to symptomatic progression $[42,43]$.

In early phase II studies, sunitinib also demonstrated activity in the treatment of advanced HCC [44,45]. However, a phase III study comparing sunitinib to sorafenib was terminated in April 2010 due to increased toxicity in the sunitinib arm; it did not meet the pre-defined criteria for superiority or non-inferiority (NCT00699374).

Two phase II studies examining the activity of singleagent bevacizumab in advanced HCC both demonstrate promising antitumour activity (RR 12.5-13\%; PFS 6.9 months) but toxicity, in particular gastrointestinal bleeding, is concerning, [46,47]. There have been three single arm phase II studies of bevacizumab in combination with a variety of chemotherapy regimens which show evidence of clinical activity but randomized comparisons are required [48-50].

\section{Biliary tract cancers (BTC)}

BTC, which include intra- and extra-hepatic cholangiocarcinoma and gallbladder malignancies, are rare tumours accounting for only 3-4\% of GI cancers. Surgery is the only curative option but most patients present with unresectable disease [51]. In patients with advanced BTC, only recently has treatment with gemcitabine and cisplatin demonstrated an improvement in OS [52].

In contrast to $\mathrm{HCC}$, BTC metastases tend to be hypovascular. However, VEGF expression in these tumors does correlate with advanced disease stage and poor prognosis $[53,54]$. A phase II clinical trial using gemcitabine and oxaliplatin (GEMOX) combined with bevacizumab demonstrated modest activity with an ORR of $40 \%$, median PFS 7.0 months and median OS of 12.7 months [55]. However, the 6-month PFS did not meet the pre-specified endpoint of an improvement from $50 \%$ to $70 \%$ as compare to GEMOX alone. Randomized comparisons are needed to evaluate the added benefit of bevacizumab. To date, attempts at TKI inhibition have not been beneficial in BTC. Two phase II clinical trials of sorafenib failed to show significant clinical activity $[56,57]$.

\section{PANCREATIC ADENOCARCINOMA}

Pancreas cancer is the fourth commonest cause of cancer-related mortality across the world, with incidence equaling mortality [58]. Only $15-20 \%$ of patients present with surgically resectable disease and, of these, only $20 \%$ will survive 5 years. The OS for patients with metastatic or locally advanced disease is 4-9 months. Gemcitabine remains the standard chemotherapy for this disease with a modest benefit in OS [59]. Multiple studies combining gemcitabine with other cytotoxic agents have not demonstrated improvement in survival [60-62]. The phase III randomized trial of gemcitabine vs gemcitabine + erlotinib, an epidermal growth factor receptor (EGFR) inhibitor did improve median OS from 5.91 months to 6.24 months but the clinical relevance of this benefit is questioned by the medical oncology community [63].

VEGF and its receptors (VEGFR-1 and VEGFR-2) 
are co-expressed in pancreatic cancer suggesting that VEGF could have autocrine effects on pancreatic cancer cells that express VEGF receptors and paracrine effects on microvascular endothelial cells [64-66]. In animal models, VEGF TKIs and anti-VEGF and anti-VEGFR-2 antibodies inhibit growth and angiogenesis associated with pancreatic tumors and potentiated the tumoricidal effect of gemcitabine [67-71].

Activity in the phase II trials combining gemcitabine and bevacizumab looked promising and, based upon these results, bevacizumab was tested in two randomized controlled phase III studies [72,73]. In these trials, gemcitabine with or without bevacizumab and gemcitabine plus erlotinib with or without bevacizumab both failed to show a survival benefit with the addition of bevacizumab $[74,75]$. Other VEGF targeted therapies tested in the setting of pancreatic cancer include sorafenib, axitinib, and sunitinib but limited activity in phase II trials ended further investigations into these agents [76-78].

\section{COLORECTAL ADENOCARCINOMAS}

Colorectal cancer is the fourth most common cancer in men and women [79]. Patients with untreated metastatic CRC (mCRC) have a median survival of $5-6$ months [80]. Prior to the emergence of the topoisomerase I inhibitor irinotecan in 1996, treatment for metastatic colorectal cancer was limited to $\mathrm{FU}$ and leucovorin (LV). This was followed in 2004, by the introduction of oxaliplatin. An analysis of several large, phase III studies demonstrates that exposure at some time during treatment to these three agents (FU plus LV, irinotecan, and oxaliplatin) significantly improves overall survival OS of mCRC to an average of 20 months [81].

In early pre-clinical work on colon cancer specimens, a correlation was noted between increased
VEGF expression and proliferative activity in tumors [82]. Furthermore, in vivo murine antihuman monoclonal antibodies targeted against VEGF inhibited growth of human tumor xenografts [83]. Based on these findings, two randomized phase II studies combining FU +LV with bevacizumab demonstrated improved clinical efficacy over FU + LV alone [84,85]. (Table 2) The landmark phase III trial by Hurwitz et al which led to the clinical approval of bevacizumab for the treatment of mCRC compared either FU + LV + irinotecan (IFL) + bevacizumab to IFL + placebo which reported a median OS of 20.3 months versus 15.6 months [14]. (Table 2) However, the IFL regimen has fallen out of favor due to the improved tolerance and efficacy of infusional FU + irinotecan (FOLFIRI) as compared to modified IFL (mIFL) [86]. This trial was then modified in April 2004 to assess the addition of bevacizumab to both of these arms of the trial with both the PFS and median OS favoring the patients receiving FOLFIRI + bevacizumab as compared to $\mathrm{mIFL}+$ bevacizumab. Although this trial did not directly compare FOLFIRI administered with or without bevacizumab, it does suggest FOLFIRI + bevacizumab is more efficacious than mIFL + bevacizumab.

The combination of bevacizumab with oxaliplatinbased chemotherapy as first line therapy has also been investigated in a randomized, double-blind study designated N016966 [87]. In this study, 1,400 patients received FU + oxaliplatin (FOLFOX) or capecitabine + oxaliplatin (XELOX), with either bevacizumab or placebo. Although an improvement in median PFS was seen, neither an improvement in RR or median OS was achieved. (Table 2) It is hypothesized that the failure to improve median OS was due to early discontinuation of the capecitabine or FU and bevacizumab when oxaliplatin peripheral neurotoxicity occurred hence diminishing the impact of bevacizumab [88]. In the second-line setting,

\begin{tabular}{|c|c|c|c|c|c|c|c|c|}
\hline \multirow{4}{*}{$\begin{array}{l}\text { First-Line Phase II Trials } \\
\text { AVF0780g }\end{array}$} & \multirow{4}{*}{$\begin{array}{l}\text { Relevant Treatment Arms } \\
\text { Roswell Park } \\
\text { Roswell Park + Bevacizumab } 5 \mathrm{mg} / \mathrm{kg} \\
\text { Roswell Park + Bevacizumab } 10 \mathrm{mg} / \mathrm{kg}\end{array}$} & \multirow{4}{*}{\begin{tabular}{l|}
$\boldsymbol{n}$ \\
36 \\
35 \\
33
\end{tabular}} & \multicolumn{2}{|c|}{ Response Rate } & \multicolumn{2}{|c|}{$\begin{array}{l}\text { Progression-Free } \\
\text { Survival }\end{array}$} & \multicolumn{2}{|c|}{ Overall Survival } \\
\hline & & & $17 \%$ & \multirow{3}{*}{$\begin{array}{l}\text { Not } \\
\text { applicable }\end{array}$} & 5.2 months & \multirow{3}{*}{$\begin{array}{l}\text { Not } \\
\text { applicable }\end{array}$} & 13.8 months & \multirow{3}{*}{$\begin{array}{l}\text { Not } \\
\text { applicable }\end{array}$} \\
\hline & & & $40 \%$ & & 9.0 months & & 21.5 months & \\
\hline & & & $24 \%$ & & 7.2 months & & 16.1 months & \\
\hline \multirow{2}{*}{ AVF2192g } & Roswell Park + Placebo & 105 & $15.2 \%$ & \multirow{2}{*}{$\begin{array}{l}\text { Not } \\
\text { applicable }\end{array}$} & 5.5 months & \multirow{2}{*}{$\begin{array}{l}\text { Not } \\
\text { applicable }\end{array}$} & 12.9 months & \multirow{2}{*}{$\begin{array}{l}\text { Not } \\
\text { applicable }\end{array}$} \\
\hline & Roswell Park + Bevacizumab & 104 & $26.0 \%$ & & 9.2 months & & 16.6 months & \\
\hline $\begin{array}{lll}\begin{array}{l}\text { First-Line } \\
\text { Trials }\end{array} & \text { Phase } & \text { III } \\
\end{array}$ & Relevant Treatment Arms & $n$ & \multicolumn{2}{|c|}{ Response Rate } & \multicolumn{2}{|c|}{$\begin{array}{c}\text { Progression-Free } \\
\text { Survival }\end{array}$} & \multicolumn{2}{|c|}{ Overall Survival } \\
\hline \multirow{2}{*}{ AVF2107g } & IFL & 411 & $34.8 \%$ & \multirow{2}{*}{$p=0.004$} & 6.2 months & \multirow{2}{*}{$\begin{array}{l}\text { HR } 0.54 \\
p<0.001\end{array}$} & 15.6 months & \multirow{2}{*}{$\begin{array}{l}\text { HR } 0.66 \\
p<0.001\end{array}$} \\
\hline & $\mathrm{IFL}+\mathrm{B}$ & 402 & $44.8 \%$ & & 10.6 months & & 20.3 months & \\
\hline \multirow{5}{*}{ BICC-C } & FOLFIRI & 144 & $47.2 \%$ & & 7.6 months & & 23.1 months & \\
\hline & mIFL & 141 & $43.3 \%$ & & 5.9 months & & 17.6 months & \\
\hline & CapeIRI & 145 & $38.6 \%$ & & 5.8 months & & 18.9 months & \\
\hline & FOLFIRI + Bevacizumab & 57 & $57.9 \%$ & & 11.2 months & & Not yet reached & \\
\hline & mIFL + Bevacizumab & 60 & $53.3 \%$ & & 8.3 months & & 19.2 months & \\
\hline \multirow{2}{*}{ NO16966 } & FOLFOX/XELOX + Placebo & 699 & $38 \%$ & \multirow{2}{*}{$\begin{array}{l}\text { OR } 1.00 \\
p=0.99\end{array}$} & 9.4 months & \multirow{2}{*}{$\begin{array}{l}\text { HR } 0.83 \\
p=0.0023\end{array}$} & 21.3 months & \multirow{2}{*}{$\begin{array}{l}\text { HR } 0.89 \\
p=0.0769\end{array}$} \\
\hline & FOLFOX/XELOX + Bevacizumab & 701 & $38 \%$ & & 8.0 months & & 19.9 months & \\
\hline $\begin{array}{l}\text { Second-Line Phase III } \\
\text { Trials }\end{array}$ & Relevant Treatment Arms & $n$ & \multicolumn{2}{|c|}{ Response Rate } & \multicolumn{2}{|c|}{$\begin{array}{l}\text { Progression-Free } \\
\text { Survival }\end{array}$} & \multicolumn{2}{|c|}{ Overall Survival } \\
\hline \multirow[b]{2}{*}{ E3200 } & FOLFOX4 & 285 & $8.6 \%$ & \multirow[b]{2}{*}{$p<0.0001$} & 4.7 months & \multirow{2}{*}{$\begin{array}{l}\text { HR } 0.61 \\
P< \\
0.0001\end{array}$} & 10.8 months & \multirow{2}{*}{$\begin{array}{l}\text { HR } 0.75 \\
p=0.001\end{array}$} \\
\hline & FOLFOX4 + Bevacizumab & 287 & $22.7 \%$ & & 7.3 months & & 12.9 months & \\
\hline
\end{tabular}

Table 2: Seminal publications supporting the use of bevacizumab in advanced colorectal cancer. Abbreviations: HR, hazards ratio; OR, odds ratio 
the addition of bevacizumab to FOLFOX improved RR, median PFS, and median OS [89]. (Table 2)

The clinical efficacy of bevacizumab in the metastatic setting led to the development of two pivotal phase III clinical trials in patients with resected stage II or III colon cancer. The NSABP C-08 study failed to show an improvement in disease-free or overall survival with the addition of bevacizumab to FOLFOX [90]. The results of the second trial, AVANT, are anticipated later this year (NCT00112918).

Several oral angiogenesis inhibitors are under investigation for the treatment of mCRC. (Table 1) Agents which have completed phase III clinical trials include valatinib and cediranib. Valatinib inhibits all known VEGF tyrosine kinase receptors. There have been two phase III studies testing this agent in mCRC. In CONFIRM-1, patients were assigned to receive first-line FOLFOX + valatinib or placebo but this study failed to meet its primary endpoint of PFS [91]. Similarly, CONFIRM-2, which was the second-line study of FOLFOX + valatinib or placebo, also did not meet its primary endpoint for OS [92]. HORIZON III is a randomized comparison of FOLFOX + cediranib (AZ2171), a highly potent and selective inhibitor of the three VEGF receptors, and FOLFOX + bevacizumab as first-line chemotherapy in mCRC. Although not yet published, a media release in March 2010 has confirmed that the study failed to meet its primary endpoint of non-inferiority for PFS [93].

\section{PROMISING NOVEL ANTIANGIOGENIC AGENTS FOR GI TUMORS}

Despite many clinical trials, the only approved antiangiogenic therapies in GI tumours are bevacizumab and sorafenib, in advanced CRC and HCC, respectively. These will be the gold standard that all other agents in their class must compete against and no others have yet

\begin{tabular}{|c|c|c|c|c|c|}
\hline $\begin{array}{l}\text { NCT Trial } \\
\text { Number }\end{array}$ & Phase & $\begin{array}{l}\text { Tumor } \\
\text { Type }\end{array}$ & $\begin{array}{l}\text { Line of } \\
\text { therapy }\end{array}$ & Control arm & Investigational arm \\
\hline NCT01046864 & $\mathrm{I}$ & $\begin{array}{l}\text { GI, not } \\
\text { pancreas }\end{array}$ & N/A & $\mathrm{N} / \mathrm{A}$ & $\begin{array}{l}\text { 5FU/LV+brivanib; FOLFIRI+brivanib } \\
\text { FOLFIRI+brivanib in Japanese }\end{array}$ \\
\hline NCT00825955 & III & $\mathrm{HCC}$ & $2^{\text {nd }}$ & BSC+placebo & BSC+brivanib \\
\hline NCT01108705 & III & $\begin{array}{l}\mathrm{HCC} \\
\text { (asian) }\end{array}$ & $2^{\text {nd }}$ & $\mathrm{BSC}+$ placebo & BSC+brivanib \\
\hline NCT00640471 & III & $\mathrm{CRC}$ & $\geq 3^{\text {rd }}$ & cetuximab+placebo & cetuximab+brivanib \\
\hline NCT00858871 & III & $\mathrm{HCC}$ & $1^{\mathrm{st}}$ & sorafenib+placebo & brivanib+placebo \\
\hline NCT00437424 & I & $\begin{array}{l}\text { HCC with } \\
\text { liver } \\
\text { dysfxn }\end{array}$ & N/A & N/A & brivanib \\
\hline NCT00594984 & $\mathrm{I} / \mathrm{II}$ & $\mathrm{CRC}$ & N/A & N/A & Irinotecan+cetuximab+brivanib \\
\hline NCT00355238 & II & $\mathrm{HCC}$ & $\geq 1^{\mathrm{st}}$ & N/A & brivanib \\
\hline NCT00207051 & I & $\begin{array}{l}\text { Advanced } \\
\text { GI }\end{array}$ & $\mathrm{N} / \mathrm{A}$ & $\mathrm{N} / \mathrm{A}$ & cetuximab+brivanib \\
\hline NCT00707889 & II & CRC & $\geq 2^{\text {nd }}$ & FOLFOX+Bev & $\begin{array}{l}\text { FOLFOX+high dose ABT-869; FOLFOX+low } \\
\text { dose ABT-869 }\end{array}$ \\
\hline NCT00517920 & II & $\mathrm{HCC}$ & N/A & $\mathrm{N} / \mathrm{A}$ & ABT-869 \\
\hline NCT01009593 & III & $\mathrm{HCC}$ & $1^{\text {st }}$ & sorafenib & ABT-869 \\
\hline NCT00753675 & II & biliary & $1 \mathrm{st}$ & gemcitabine + placebo & AZD6474+placebo; AZD6474+gemcitabine \\
\hline NCT00500292 & II & $\mathrm{CRC}$ & $2^{\text {nd }}$ & FOLFOX+placebo & $\begin{array}{l}\text { FOLFOX+low dose AZD6474; FOLFOX+high } \\
\text { dose AZD6474 }\end{array}$ \\
\hline NCT00508001 & II & $\mathrm{HCC}$ & $1^{\mathrm{st}}$ & BCS+placebo & $\begin{array}{l}\text { BSC+ low dose AZD6474; } \\
\text { BSC+high dose AZD6474 }\end{array}$ \\
\hline NCT00454116 & II & CRC & $2^{\text {nd }}$ & FOLFIRI+placebo & $\begin{array}{l}\text { FOLFIRI+low dose AZD6474; } \\
\text { FOLFIRI+high dose AZD6474 }\end{array}$ \\
\hline NCT00436072 & I & CRC & & N/A & $\begin{array}{l}\text { cetuximab+AZD6474; } \\
\text { irinotecan+cetuximab+AZD6474 }\end{array}$ \\
\hline NCT00681798 & I & Pancreas & any & $\mathrm{N} / \mathrm{A}$ & gemcitabine+capecitabine+AZD6474 \\
\hline NCT00732745 & $\mathrm{I} / \mathrm{II}$ & $\begin{array}{l}\text { Esophagus } \\
\text { GEJ }\end{array}$ & Any & docetaxel+oxaliplatin & docetaxel+oxaliplatin+AZD6474 \\
\hline NCT00499850 & I & CRC & Any & N/A & FOLFOX+AZD6474 \\
\hline NCT00532909 & I & $\mathrm{CRC}$ & any & $\mathrm{N} / \mathrm{A}$ & capecitabine+oxaliplatin+cetuximab+AZD6474 \\
\hline NCT00683787 & II & gastroesop & $\leq 2^{\text {nd }}$ & docetaxel & $\begin{array}{l}\text { docetaxel+low dose AZD6474; } \\
\text { docetaxel+high dose AZD6474 }\end{array}$ \\
\hline
\end{tabular}

Table 3: Ongoing clinical trials with anti-VEGF TKIs. Abbreviations: GI, gastrointestinal; HCC, hepatocellular; N/A, not applicable; Bev, bevacizumab; CRC, colorectal cancer; GEJ, gastroesophageal junction 
been successful. Additionally, there are no approved indications in gastroesophageal and pancreatic cancers for antiangiogenic compounds. Nonetheless, multiple other novel agents are currently under investigation. Below is a summary of the most promising agents that may prove beneficial in patients with GI malignancies.

\section{SMALL MOLECULE TKIS}

\section{Brivanib alaninate}

Brivanib alaninate is an oral small molecule TKI active against VEGFR-1, VEGFR-2, VEGFR-3, and fibroblast growth factor (FGF) receptor (FGFR). The FGF pathway has a demonstrated role in cancer progression and FGF level are elevated akin to VEGF levels in malignancy $[94,95]$. Dual blockade of VEGFRs and FGFR is attractive clinically as FGF signaling has been implicated in resistance to VEGFR inhibition [96]. There is particular interest in the development of this drug in some GI malignancies due to particularly high levels of FGF in HCC and the known FGF overexpression in gastric cancer [97,98]. Multiple phase I studies have demonstrated safety of brivanib both alone and in combination with cytotoxics. Ongoing trials in GI cancers are listed in table 3 .

\section{ABT-869}

ABT-869 is an oral potent TKI inhibitor of VEGFR-1, VEGFR-2, VEGFR-3, PDGFRß, and Flt3 [99,100]. Data suggests ABT-869 is more selective toward VEGFR and PDGFR than other similar TKIs while also having apoptotic effects [101]. Efficacy was seen with this drug in colorectal xenografts models [101]. A phase I dose escalation study recently published reported drug tolerability with toxicities including proteinuria, hypertension, fatigue, hand-foot blistering, and myalgias [99]. Three patients achieved partial response with $48 \%$ of patients recording stable disease. Effective antiangiogenesis was noted on dynamic contrast enhanced magnetic resonance imaging (DCE-MRI) which may act as a biomarker after further evaluation. The majority of clinical development of this agent is ongoing in CRC and HCC. Interim results from a phase II study in ChildPugh A and B HCC reported tolerable toxicities and 42\% of evaluable patients were progression free at 16 weeks [102]. Other ongoing GI trials using ABT-869 are listed in table 3 .

\section{ZD6474}

ZD6474 is a TKI potently inhibiting VEGFR-2, Rearranged during Transfection (RET), Flt-4, and EGFR $[103,104]$. Initial dose finding studies in patients with advanced solid malignancies who had failed standard of care treatments report good tolerability at doses $<300 \mathrm{mg}$ $[105,106]$. As preclinical data supported use in a wide spectrum of human malignancies, clinical development of AZ6474 has been across multiple tumor types. In colon cancers, ZD6474 has been combined with FOLFIRI and FOLFOX with good tolerability $[107,108]$. A phase II study of FOLFIRI plus ZD6474 did not confirm benefit with the combination [109]. A combination of gemcitabine + capecitabine + ZD6474 in biliary and pancreatic cancer has shown promising early clinical results [110]. There is additional preclinical data supporting ZD6474 use in gastric cancers [111,112]. Ongoing clinical trials in GI cancers are listed in table 3 .

\section{INHIBITING VEGFRS}

\section{Ramucirumab}

\begin{tabular}{|l|l|l|l|l|l|}
\hline $\begin{array}{l}\text { NCT Trial } \\
\text { Number }\end{array}$ & Phase & $\begin{array}{l}\text { Tumor } \\
\text { Type }\end{array}$ & $\begin{array}{l}\text { Line of } \\
\text { therapy }\end{array}$ & Control arm & Investigational arm \\
\hline \hline NCT01140347 & III & HCC & 2nd & BSC & ramucirumab \\
\hline NCT01170663 & III & gastric & 2nd & paclitaxel+placebo & paclitaxel+ramucirumab \\
\hline NCT01183780 & III & CRC & 2nd & FOLFIRI+placebo & FOLFIRI+ramucirumab \\
\hline NCT01079780 & II & CRC & $\begin{array}{l}\geq 2^{\text {nd }} \\
\text { post } \\
\text { Bev }\end{array}$ & irinotecan+cetuximab & Irinotecan+cetuximab+ramucirumab \\
\hline NCT01111604 & II/III & CRC & 2nd & FOLFOX & $\begin{array}{l}\text { FOLFOX+ramucirumab; } \\
\text { FOLFOX+IMC-18F1 }\end{array}$ \\
\hline NCT00917384 & III & gastric & 2ND & placebo+BSC & Ramucirumab+BSC \\
\hline
\end{tabular}

Table 4: Ongoing clinical trials with anti-VEGFR mAbs. Abbreviations: HCC, hepatocellular; CRC, colorectal; BSC, best supportive care; Bev, bevacizu 
Ramucirumab is a fully human mAb with low pM affinity to the VEGF-binding domain of VEGFR-2 [113]. Dose-finding studies were undertaken with weekly and every 2 and 3 week single agent administration with very good drug tolerance $[114,115]$. Common toxicities were as expected based on the antibodies' mechanism of action and included thrombotic events, hypertension, proteinuria, and bleeding. Initial reports suggest a greater clinical benefit with the use of ramucirumab than other clinically tested antiangiogenic agents, though randomized clinical trials must be undertaken to prove superiority $[114,116]$. More advanced studies using a dose of $8 \mathrm{mg} / \mathrm{kg}$ every 2 weeks are ongoing and listed in table 4. Early data from the phase II study of ramucirumab used in the first-line setting in Childs-Pugh A and B HCC is promising in sorafenib-naïve patients with a $50 \%$ disease control rate [117].

\section{IMC-18F1}

IMC-18F1 has had a slower clinical development compared to ramucirumab. An intravenous recombinant human $\mathrm{IgG}_{1}$ anti-VEGFR-1 mAb, IMC-18F1 inhibits ligand-induced VEGFR-1 activation at low pM concentrations [118]. Final data from a multi-schedule phase I single agent dose finding study is pending but preliminary information revealed safely and biologic activity supporting further development of the drug [119]. Clinical development of IMC-18F1 is listed in table 4.

\section{Decoy fusion proteins}

Aflibercept, a novel fully human recombinant decoy fusion protein, has recently completed phase I clinical testing [120,121]. Mimicking immunoglobin domains of VEGFR-1 and VEGFR-2, it has low pM affinity for VEGF, VEGF-B and PIGF [122,123]. When administered intravenously every 2 weeks, aflibercept was well tolerated with rectal ulceration and proteinuria being the dose limiting toxicities. Other toxicities were in keeping with inhibition of the VEGF/VEGFR pathway. Three patients experienced a partial response. A phase II study in metastatic CRC has also demonstrated benefit in a bevacizumab pre-treated cohort prompting further investigations in this area [124]. Ongoing studies with aflibercept in GI malignancies are listed in table 5.

\section{SUMMARY}

Antiangiogenic agents have clearly advanced the treatment of GI malignancies, most notably CRC and HCC. Unfortunately, there have been no advances in the treatment of incurable EGC and pancreas cancer using antiangiogenic agents and prognosis remains poor. Despite the promising results in $\mathrm{CRC}$ with bevacizumab and $\mathrm{HCC}$ with sorafenib, multiple clinical trials using other methods of blocking the VEGF pathway have been negative in these and the other GI malignancies. The mechanisms of resistance to VEGF inhibition is not known. Despite preclinical models suggesting that VEGF inhibition should be effective in all GI malignancies; this has not been confirmed in clinical practice.

Uncertainty exists in many of these negative trials as to why the study or drug failed. Likely, the answer is multifactorial being related to a combination of drug ineffectiveness once used in a randomized phase III setting, poor clinical trial design, suboptimal patient selection, and lack of a reliable biomarker to direct clinicians on which patients will or will not benefit. The importance of predictors for treatment response of these agents are exemplified well by the results of the AVAGAST study

\begin{tabular}{|l|l|l|l|l|l|}
\hline $\begin{array}{l}\text { NCT Trial } \\
\text { Number }\end{array}$ & Phase & $\begin{array}{l}\text { Tumor } \\
\text { Type }\end{array}$ & $\begin{array}{l}\text { Line of } \\
\text { therapy }\end{array}$ & $\begin{array}{l}\text { Control } \\
\text { arm }\end{array}$ & Investigational arm \\
\hline \hline NCT00574275 & III & pancreatic & $2^{\text {nd }}$ & placebo & aflibercept \\
\hline NCT00561470 & III & $\begin{array}{l}\text { advanced } \\
\text { CRC }\end{array}$ & $2^{\text {nd }}$ & $\begin{array}{l}\text { irinotecan } \\
+5 \text { FU }\end{array}$ & irinotecan+5FU+aflibercept \\
\hline NCT00851084 & II & $\begin{array}{l}\text { advanced } \\
\text { CRC }\end{array}$ & $1^{\text {st }}$ & FOLFOX & FOLFOX+aflibercept \\
\hline NCT00407654 & II & $\begin{array}{l}\text { advanced } \\
\text { CRC }\end{array}$ & $\pm 2^{\text {nd }}$ & N/A & aflibercept \\
\hline NCT00921661 & I & $\begin{array}{l}\text { advanced } \\
\text { CRC in } \\
\text { Japanese }\end{array}$ & N/A & N/A & FOLFIRI+aflibercept \\
\hline
\end{tabular}

Table 5: Ongoing clinical trials with aflibercept. Abbreviations: CRC, colorectal cancer; 5FU, \%-fluorouracil; N/A, not applicable 
suggesting that there is a patient population which may benefit from the addition of an angiogenesis inhibitor, but when studied in a general patient population, a survival benefit could not be attained. Biomarkers are needed to delineate those patients who will benefit and those who will not.

In $\mathrm{CRC}$, investigations are underway to determine genetic profiles or other patient characteristics to help identify those who will benefit from anti-angiogenic inhibition. Until trials can clarify the optimal use of these agents, data supports exposure, at some point in the treatment of $\mathrm{mCRC}$, to bevacizumab in fit patients. In all GI tumors, the use of newer genetically engineered cancer models may help elucidate mechanisms of resistance or biomarkers to aid clinician treatment choices [125]. Additionally, though not necessarily practical, the use of newer imaging techniques, like DCE-MRI, may play a role in early determination of antiangiogenic efficacy.

Until the time when biomarkers are identified and validated to predict effectiveness of these agents, we may be wasting precious resources in trying to develop antiangiogenic agents further. New agents look attractive but intelligent clinical trial development will be required to find these new drugs a niche in an already saturated area of cancer treatment.

\section{ACKNOWLEDGMENTS}

The authors would like to thank Brian Brady for his reproduction of Figure 1.

\section{REFERENCES}

1. Carmeliet P: Angiogenesis in life, disease and medicine. Nature 2005;438:932-936.

2. Carmeliet P, Jain RK: Angiogenesis in cancer and other diseases. Nature 2000;407:249-257.

3. Folkman J: Angiogenesis in cancer, vascular, rheumatoid and other disease. Nat Med 1995;1:27-31.

4. Veikkola T, Alitalo K: VEGFs, receptors and angiogenesis. Semin Cancer Biol 1999;9:211-220.

5. Ferrara N: VEGF as a therapeutic target in cancer. Oncology 2005;69 Suppl 3:11-16.

6. Klagsbrun M, D'Amore PA: Vascular endothelial growth factor and its receptors. Cytokine Growth Factor Rev 1996;7:259-270.

7. Leung DW, Cachianes G, Kuang WJ, Goeddel DV, Ferrara N: Vascular endothelial growth factor is a secreted angiogenic mitogen. Science 1989;246:1306-1309.

8. Neufeld G, Cohen T, Gengrinovitch S, Poltorak Z: Vascular endothelial growth factor (VEGF) and its receptors. Faseb J 1999;13:9-22.

9. Inoue M, Hager JH, Ferrara N, Gerber HP, Hanahan D: VEGF-A has a critical, nonredundant role in angiogenic switching and pancreatic beta cell carcinogenesis. Cancer Cell 2002;1:193-202.

10. Gille H, Kowalski J, Li B, LeCouter J, Moffat B, Zioncheck TF, Pelletier N, Ferrara N: Analysis of biological effects and signaling properties of Flt-1 (VEGFR-1) and KDR (VEGFR-2). A reassessment using novel receptor-specific vascular endothelial growth factor mutants. J Biol Chem 2001;276:3222-3230.

11. de Vries C, Escobedo JA, Ueno H, Houck K, Ferrara N, Williams LT: The fms-like tyrosine kinase, a receptor for vascular endothelial growth factor. Science 1992;255:989991.

12. Plate KH, Breier G, Millauer B, Ullrich A, Risau W: Up-regulation of vascular endothelial growth factor and its cognate receptors in a rat glioma model of tumor angiogenesis. Cancer Res 1993;53:5822-5827.

13. Plate KH, Breier G, Weich HA, Mennel HD, Risau W: Vascular endothelial growth factor and glioma angiogenesis: coordinate induction of VEGF receptors, distribution of VEGF protein and possible in vivo regulatory mechanisms. Int J Cancer 1994;59:520-529.

14. Hurwitz H, Fehrenbacher L, Novotny W, Cartwright T, Hainsworth J, Heim W, Berlin J, Baron A, Griffing S, Holmgren E, Ferrara N, Fyfe G, Rogers B, Ross R, Kabbinavar F: Bevacizumab plus irinotecan, fluorouracil, and leucovorin for metastatic colorectal cancer. N Engl J Med 2004;350:2335-2342.

15. Parkin DM, Bray F, Ferlay J, Pisani P: Global cancer statistics, 2002. CA Cancer J Clin 2005;55:74-108.

16. Glimelius B, Ekstrom K, Hoffman K, Graf W, Sjoden PO, Haglund U, Svensson C, Enander LK, Linne T, Sellstrom H, Heuman R: Randomized comparison between chemotherapy plus best supportive care with best supportive care in advanced gastric cancer. Ann Oncol 1997;8:163168.

17. Murad AM, Santiago FF, Petroianu A, Rocha PR, Rodrigues MA, Rausch M: Modified therapy with 5-fluorouracil, doxorubicin, and methotrexate in advanced gastric cancer. Cancer 1993;72:37-41.

18. Pyrhonen S, Kuitunen T, Nyandoto P, Kouri M: Randomised comparison of fluorouracil, epidoxorubicin and methotrexate (FEMTX) plus supportive care with supportive care alone in patients with non-resectable gastric cancer. Br J Cancer 1995;71:587-591.

19. Wagner AD, Grothe W, Haerting J, Kleber G, Grothey A, Fleig WE: Chemotherapy in advanced gastric cancer: a systematic review and meta-analysis based on aggregate data. J Clin Oncol 2006;24:2903-2909.

20. Eroglu A, Demirci S, Ayyildiz A, Kocaoglu H, Akbulut $\mathrm{H}$, Akgul H, Elhan HA: Serum concentrations of vascular endothelial growth factor and nitrite as an estimate of in vivo nitric oxide in patients with gastric cancer. $\mathrm{Br} \mathrm{J}$ Cancer 1999;80:1630-1634.

21. Karayiannakis AJ, Syrigos KN, Polychronidis A, Zbar A, 
Kouraklis G, Simopoulos C, Karatzas G: Circulating VEGF levels in the serum of gastric cancer patients: correlation with pathological variables, patient survival, and tumor surgery. Ann Surg 2002;236:37-42.

22. Maeda K, Chung YS, Ogawa Y, Takatsuka S, Kang SM, Ogawa M, Sawada T, Sowa M: Prognostic value of vascular endothelial growth factor expression in gastric carcinoma. Cancer 1996;77:858-863.

23. Yoshikawa T, Tsuburaya A, Kobayashi O, Sairenji M, Motohashi H, Yanoma S, Noguchi Y: Plasma concentrations of VEGF and $\mathrm{bFGF}$ in patients with gastric carcinoma. Cancer Lett 2000;153:7-12.

24. Kanai T, Konno H, Tanaka T, Baba M, Matsumoto K, Nakamura S, Yukita A, Asano M, Suzuki H, Baba S: Anti-tumor and anti-metastatic effects of humanvascular-endothelial-growth-factor-neutralizing antibody on human colon and gastric carcinoma xenotransplanted orthotopically into nude mice. Int J Cancer 1998;77:933936.

25. Shah MA, Ramanathan RK, Ilson DH, Levnor A, D’Adamo D, O'Reilly E, Tse A, Trocola R, Schwartz L, Capanu M, Schwartz GK, Kelsen DP: Multicenter phase II study of irinotecan, cisplatin, and bevacizumab in patients with metastatic gastric or gastroesophageal junction adenocarcinoma. J Clin Oncol 2006;24:5201-5206.

26. Enzinger PC, Fidias P, Meyerhardt J, Stuart K, Fuchs C, Huberman M, Goldstein R, Attawia M, Lawrence C, Zhu AX: Phase II study of bevacizumab and docetaxel in metastatic esophageal and gastric cancer. 2006 Gastrointestinal Cancers Symposium 2006; General Poster Session B Abstract No:68

27. Cohenuram MK, Lacy J: FOLFOX6 and bevacizumab (FOLFOX6/B) for metastatic esophageal (E), gastroesophageal (GE), and gastric (G) adenocarcinoma: A single institution's initial clinical experience. 2008 Gastrointestinal Cancers Symposium 2008; General Poster Session A. Abstract No:74

28. Hammad N, Philip PA, Shields AF, Heilbrun LK, ElRayes BF: A phase II study of bevacizumab, docetaxel, and oxaliplatin in gastric and gastroesophageal junction (GEJ) cancer. 2008 Gastrointestinal Cancers Symposium 2008;General Poster Session A. Abstract No:30

29. Kang Y, Ohtsu A, Cutsem EV, Rha SY, Sawaki A, Park S, Lim H, Wu J, Langer B, Shah MA: AVAGAST: A randomized, double-blind, placebo-controlled, phase III study of first-line capecitabine and cisplatin plus bevacizumab or placebo in patients with advanced gastric cancer (AGC). J Clin Oncol 2010;28:18s, 2010 (suppl; abstr LBA4007)

30. Sun W, Powell M, O'Dwyer PJ, Catalano P, Ansari RH, Benson AB, 3rd: Phase II study of sorafenib in combination with docetaxel and cisplatin in the treatment of metastatic or advanced gastric and gastroesophageal junction adenocarcinoma: ECOG 5203. J Clin Oncol 2010;28:2947-
2951.

31. Bang YJ, Kang YK, Kang WK, Boku N, Chung HC, Chen JS, Doi T, Sun Y, Shen L, Qin S, Ng WT, Tursi JM, Lechuga MJ, Lu DR, Ruiz-Garcia A, Sobrero A: Phase II study of sunitinib as second-line treatment for advanced gastric cancer. Invest New Drugs 2010.

32. Ferlay J, Shin HR, Bray F, Forman D, Mathers C, Parkin DM: GLOBOCAN 2008, Cnacer Incidence and Mortality Worldwide: IARC CanceBase No.10. In, International Agency for Research on Cancer, 2010.

33. Lopez PM, Villanueva A, Llovet JM: Systematic review: evidence-based management of hepatocellular carcinoma-an updated analysis of randomized controlled trials. Aliment Pharmacol Ther 2006;23:1535-1547.

34. Finn RS: Development of molecularly targeted therapies in hepatocellular carcinoma: where do we go now? Clin Cancer Res 2010;16:390-397.

35. Poon RT, Lau C, Pang R, Ng KK, Yuen J, Fan ST: High serum vascular endothelial growth factor levels predict poor prognosis after radiofrequency ablation of hepatocellular carcinoma: importance of tumor biomarker in ablative therapies. Ann Surg Oncol 2007;14:1835-1845.

36. Poon RT, Lau CP, Cheung ST, Yu WC, Fan ST: Quantitative correlation of serum levels and tumor expression of vascular endothelial growth factor in patients with hepatocellular carcinoma. Cancer Res 2003;63:3121-3126.

37. $\mathrm{Ng} \mathrm{IO}$, Poon RT, Lee JM, Fan ST, Ng M, Tso WK: Microvessel density, vascular endothelial growth factor and its receptors Flt-1 and Flk-1/KDR in hepatocellular carcinoma. Am J Clin Pathol 2001;116:838-845.

38. Jeng KS, Sheen IS, Wang YC, Gu SL, Chu CM, Shih SC, Wang PC, Chang WH, Wang HY: Prognostic significance of preoperative circulating vascular endothelial growth factor messenger RNA expression in resectable hepatocellular carcinoma: a prospective study. World J Gastroenterol 2004;10:643-648.

39. Mise M, Arii S, Higashituji H, Furutani M, Niwano M, Harada T, Ishigami S, Toda Y, Nakayama H, Fukumoto M, Fujita J, Imamura M: Clinical significance of vascular endothelial growth factor and basic fibroblast growth factor gene expression in liver tumor. Hepatology 1996;23:455464.

40. Abou-Alfa GK, Schwartz L, Ricci S, Amadori D, Santoro A, Figer A, De Greve J, Douillard JY, Lathia C, Schwartz B, Taylor I, Moscovici M, Saltz LB: Phase II study of sorafenib in patients with advanced hepatocellular carcinoma. J Clin Oncol 2006;24:4293-4300.

41. Abou-Alfa GK, Amadori D, Santoro A, Figer A, Greve JD, Lathia C, Voliotis D, Anderson S, Moscovici M, Ricci $\mathrm{S}$ : Is sorafenib (S) safe and effective in patients (pts) with hepatocellular carcinoma (HCC) and Child-Pugh B (CPB) cirrhosis? J Clin Oncol 2008;26: (May 20 suppl; abstr 4518)

42. Llovet JM, Ricci S, Mazzaferro V, Hilgard P, Gane E, 
Blanc JF, de Oliveira AC, Santoro A, Raoul JL, Forner A, Schwartz M, Porta C, Zeuzem S, Bolondi L, Greten TF, Galle PR, Seitz JF, Borbath I, Haussinger D, Giannaris T, Shan M, Moscovici M, Voliotis D, Bruix J: Sorafenib in advanced hepatocellular carcinoma. $\mathrm{N}$ Engl J Med 2008;359:378-390.

43. Cheng AL, Kang YK, Chen Z, Tsao CJ, Qin S, Kim JS, Luo R, Feng J, Ye S, Yang TS, Xu J, Sun Y, Liang H, Liu J, Wang J, Tak WY, Pan H, Burock K, Zou J, Voliotis D, Guan Z: Efficacy and safety of sorafenib in patients in the Asia-Pacific region with advanced hepatocellular carcinoma: a phase III randomised, double-blind, placebocontrolled trial. Lancet Oncol 2009;10:25-34.

44. Zhu AX, Sahani DV, Duda DG, di Tomaso E, Ancukiewicz M, Catalano OA, Sindhwani V, Blaszkowsky LS, Yoon SS, Lahdenranta J, Bhargava P, Meyerhardt J, Clark JW, Kwak EL, Hezel AF, Miksad R, Abrams TA, Enzinger PC, Fuchs CS, Ryan DP, Jain RK: Efficacy, safety, and potential biomarkers of sunitinib monotherapy in advanced hepatocellular carcinoma: a phase II study. J Clin Oncol 2009;27:3027-3035.

45. Faivre S, Raymond E, Boucher E, Douillard J, Lim HY, Kim JS, Zappa M, Lanzalone S, Lin X, Deprimo S, Harmon C, Ruiz-Garcia A, Lechuga MJ, Cheng AL: Safety and efficacy of sunitinib in patients with advanced hepatocellular carcinoma: an open-label, multicentre, phase II study. Lancet Oncol 2009;10:794-800.

46. Siegel AB, Cohen EI, Ocean A, Lehrer D, Goldenberg A, Knox JJ, Chen H, Clark-Garvey S, Weinberg A, Mandeli J, Christos P, Mazumdar M, Popa E, Brown RS, Jr., Rafii S, Schwartz JD: Phase II trial evaluating the clinical and biologic effects of bevacizumab in unresectable hepatocellular carcinoma. J Clin Oncol 2008;26:29922998.

47. Malka D, Dromain C, Farace F, Horn S, Pignon J, Ducreux $\mathrm{M}$, Boige V: Bevacizumab in patients (pts) with advanced hepatocellular carcinoma (HCC): Preliminary results of a phase II study with circulating endothelial cell (CEC) monitoring. Journal of Clinical Oncology, 2007 ASCO Annual Meeting Proceedings Part I. 2007;Vol 25, No. 18S (June 20 Supplement), 2007: 4570

48. Hsu CH, Yang TS, Hsu C, Toh HC, Epstein RJ, Hsiao LT, Chen PJ, Lin ZZ, Chao TY, Cheng AL: Efficacy and tolerability of bevacizumab plus capecitabine as first-line therapy in patients with advanced hepatocellular carcinoma. Br J Cancer 2010;102:981-986.

49. Zhu AX, Blaszkowsky LS, Ryan DP, Clark JW, Muzikansky A, Horgan K, Sheehan S, Hale KE, Enzinger PC, Bhargava P, Stuart K: Phase II study of gemcitabine and oxaliplatin in combination with bevacizumab in patients with advanced hepatocellular carcinoma. J Clin Oncol 2006;24:18981903.

50. Sun W, Haller DG, Mykulowycz K, Rosen M, Soulen M, Capparo M, Faust T, Giantonia B, Olthoff K: Combination of capecitabine, oxaliplatin with bevacizumab in treatment of advanced hepatocellular carcinoma (HCC): A phase II study. Journal of Clinical Oncology, 2007 ASCO Annual Meeting Proceedings Part I. 2007; Vol 25, No. 18S (June 20 Supplement), 2007: 4574.

51. Leonard GD, O'Reilly EM: Biliary tract cancers: current concepts and controversies. Expert Opin Pharmacother 2005;6:211-223.

52. Valle J, Wasan H, Palmer DH, Cunningham D, Anthoney A, Maraveyas A, Madhusudan S, Iveson T, Hughes S, Pereira SP, Roughton M, Bridgewater J: Cisplatin plus gemcitabine versus gemcitabine for biliary tract cancer. $\mathrm{N}$ Engl J Med;362:1273-1281.

53. Hida Y, Morita T, Fujita M, Miyasaka Y, Horita S, Fujioka Y, Nagashima K, Katoh H: Vascular endothelial growth factor expression is an independent negative predictor in extrahepatic biliary tract carcinomas. Anticancer Res 1999;19:2257-2260.

54. Giatromanolaki A, Koukourakis MI, Simopoulos C, Polychronidis A, Sivridis E: Vascular endothelial growth factor (VEGF) expression in operable gallbladder carcinomas. Eur J Surg Oncol 2003;29:879-883.

55. Zhu AX, Meyerhardt JA, Blaszkowsky LS, Kambadakone AR, Muzikansky A, Zheng H, Clark JW, Abrams TA, Chan JA, Enzinger PC, Bhargava P, Kwak EL, Allen JN, Jain SR, Stuart K, Horgan K, Sheehan S, Fuchs CS, Ryan DP, Sahani DV: Efficacy and safety of gemcitabine, oxaliplatin, and bevacizumab in advanced biliary-tract cancers and correlation of changes in 18-fluorodeoxyglucose PET with clinical outcome: a phase 2 study. Lancet Oncol 2010;11:48-54.

56. Bengala C, Bertolini F, Malavasi N, Boni C, Aitini E, Dealis C, Zironi S, Depenni R, Fontana A, Del Giovane C, Luppi G, Conte P: Sorafenib in patients with advanced biliary tract carcinoma: a phase II trial. Br J Cancer 2010;102:6872.

57. El-Khoueiry AB, Rankin C, Lenz HJ, Philip P, Rivkin SE, Blanke CD: SWOG 0514: A phase II study of sorafenib (BAY 43-9006) as single agent in patients (pts) with unresectable or metastatic gallbladder cancer or cholangiocarcinomas. Journal of Clinical Oncology, 2007 ASCO Annual Meeting Proceedings Part I. 2007; Vol 25, No. 18S (June 20 Supplement): 4639.

58. Hariharan D, Saied A, Kocher HM: Analysis of mortality rates for pancreatic cancer across the world. HPB (Oxford) 2008;10:58-62.

59. Burris HA, 3rd, Moore MJ, Andersen J, Green MR, Rothenberg ML, Modiano MR, Cripps MC, Portenoy RK, Storniolo AM, Tarassoff P, Nelson R, Dorr FA, Stephens $\mathrm{CD}$, Von Hoff DD: Improvements in survival and clinical benefit with gemcitabine as first-line therapy for patients with advanced pancreas cancer: a randomized trial. J Clin Oncol 1997; 15:2403-2413.

60. Berlin JD, Catalano P, Thomas JP, Kugler JW, Haller $\mathrm{DG}$, Benson AB, 3rd: Phase III study of gemcitabine in combination with fluorouracil versus gemcitabine alone 
in patients with advanced pancreatic carcinoma: Eastern Cooperative Oncology Group Trial E2297. J Clin Oncol 2002;20:3270-3275.

61. Louvet C, Labianca R, Hammel P, Lledo G, Zampino MG, Andre T, Zaniboni A, Ducreux M, Aitini E, Taieb J, Faroux $\mathrm{R}$, Lepere C, de Gramont A: Gemcitabine in combination with oxaliplatin compared with gemcitabine alone in locally advanced or metastatic pancreatic cancer: results of a GERCOR and GISCAD phase III trial. J Clin Oncol 2005;23:3509-3516.

62. Cunningham D, Chau I, Stocken DD, Valle JW, Smith D, Steward W, Harper PG, Dunn J, Tudur-Smith C, West J, Falk S, Crellin A, Adab F, Thompson J, Leonard P, Ostrowski J, Eatock M, Scheithauer W, Herrmann R, Neoptolemos JP: Phase III randomized comparison of gemcitabine versus gemcitabine plus capecitabine in patients with advanced pancreatic cancer. J Clin Oncol 2009;27:5513-5518.

63. Moore MJ, Goldstein D, Hamm J, Figer A, Hecht JR, Gallinger S, Au HJ, Murawa P, Walde D, Wolff RA, Campos D, Lim R, Ding K, Clark G, Voskoglou-Nomikos T, Ptasynski M, Parulekar W: Erlotinib plus gemcitabine compared with gemcitabine alone in patients with advanced pancreatic cancer: a phase III trial of the National Cancer Institute of Canada Clinical Trials Group. J Clin Oncol 2007;25:1960-1966.

64. Itakura J, Ishiwata T, Shen B, Kornmann M, Korc M: Concomitant over-expression of vascular endothelial growth factor and its receptors in pancreatic cancer. Int $\mathrm{J}$ Cancer 2000;85:27-34.

65. Luo J, Guo P, Matsuda K, Truong N, Lee A, Chun C, Cheng SY, Korc M: Pancreatic cancer cell-derived vascular endothelial growth factor is biologically active in vitro and enhances tumorigenicity in vivo. Int J Cancer 2001;92:361369.

66. von Marschall Z, Cramer T, Hocker M, Burde R, Plath T, Schirner M, Heidenreich R, Breier G, Riecken EO, Wiedenmann B, Rosewicz S: De novo expression of vascular endothelial growth factor in human pancreatic cancer: evidence for an autocrine mitogenic loop. Gastroenterology 2000;119:1358-1372.

67. Baker CH, Solorzano CC, Fidler IJ: Blockade of vascular endothelial growth factor receptor and epidermal growth factor receptor signaling for therapy of metastatic human pancreatic cancer. Cancer Res 2002;62:1996-2003.

68. Solorzano CC, Baker CH, Bruns CJ, Killion JJ, Ellis LM, Wood J, Fidler IJ: Inhibition of growth and metastasis of human pancreatic cancer growing in nude mice by PTK 787/ZK222584, an inhibitor of the vascular endothelial growth factor receptor tyrosine kinases. Cancer Biother Radiopharm 2001;16:359-370.

69. Bockhorn M, Tsuzuki Y, Xu L, Frilling A, Broelsch CE, Fukumura D: Differential vascular and transcriptional responses to anti-vascular endothelial growth factor antibody in orthotopic human pancreatic cancer xenografts. Clin Cancer Res 2003;9:4221-4226.
70. Tsuzuki Y, Mouta Carreira C, Bockhorn M, Xu L, Jain RK, Fukumura D: Pancreas microenvironment promotes VEGF expression and tumor growth: novel window models for pancreatic tumor angiogenesis and microcirculation. Lab Invest 2001;81:1439-1451.

71. Bruns CJ, Shrader M, Harbison MT, Portera C, Solorzano CC, Jauch KW, Hicklin DJ, Radinsky R, Ellis LM: Effect of the vascular endothelial growth factor receptor-2 antibody DC101 plus gemcitabine on growth, metastasis and angiogenesis of human pancreatic cancer growing orthotopically in nude mice. Int J Cancer 2002;102:101108.

72. Kindler HL, Friberg G, Singh DA, Locker G, Nattam S, Kozloff M, Taber DA, Karrison T, Dachman A, Stadler WM, Vokes EE: Phase II trial of bevacizumab plus gemcitabine in patients with advanced pancreatic cancer. J Clin Oncol 2005;23:8033-8040.

73. Kindler HL, Gangadhar T, Karrison T, Hochster HS, Moore MJ, Micetich K, Sun W, Catenacci DV, Stadler WM, Vokes EE: Final analysis of a randomized phase II study of bevacizumab (B) and gemcitabine (G) plus cetuximab (C) or erlotinib (E) in patients (pts) with advanced pancreatic cancer (PC). J Clin Oncol 26: 2008 (May 20 suppl; abstr 4502) 2008.

74. Kindler HL, Niedzwiecki D, Hollis D, Sutherland S, Schrag D, Hurwitz H, Innocenti F, Mulcahy MF, O'Reilly E, Wozniak TF, Picus J, Bhargava P, Mayer RJ, Schilsky RL, Goldberg RM: Gemcitabine Plus Bevacizumab Compared With Gemcitabine Plus Placebo in Patients With Advanced Pancreatic Cancer: Phase III Trial of the Cancer and Leukemia Group B (CALGB 80303). J Clin Oncol 2010;28 (22):3617-3622.

75. Van Cutsem E, Vervenne WL, Bennouna J, Humblet Y, Gill S, Van Laethem JL, Verslype C, Scheithauer W, Shang A, Cosaert J, Moore MJ: Phase III trial of bevacizumab in combination with gemcitabine and erlotinib in patients with metastatic pancreatic cancer. J Clin Oncol 2009;27:22312237.

76. Wallace JA, Locker G, Nattam S, Kasza K, Wade-Oliver K, Stadler WM, Vokes EE, Kindler HL: Sorafenib (S) plus gemcitabine $(\mathrm{G})$ for advanced pancreatic cancer (PC): A phase II trial of the University of Chicago Phase II Consortium. Journal of Clinical Oncology, 2007 ASCO Annual Meeting Proceedings Part I. Vol 25, No. 18S (June 20 Supplement), 2007: 46082007.

77. O'Reilly EM, Niedzwiecki D, Hollis DR, Bekaii-Saab TS, Pluard T, Duffy A, Overcash F, Ivy SP, Goldberg RM: A phase II trial of sunitinib (S) in previously-treated pancreas adenocarcinoma (PAC), CALGB 80603. J Clin Oncol 26: 2008 (May 20 suppl; abstr 4515) 2008.

78. Spano J, Chodkiewicz C, Maurel J, Wong RP, Wasan HS, Pithavala YK, Bycott PW, Liau K, Kim S, Rixe O: A randomized phase II study of axitinib (AG-013736) and gemcitabine versus gemcitabine in advanced pancreatic cancer, preceded by a phase I component. Journal of Clinical 
Oncology, 2007 ASCO Annual Meeting Proceedings Part I. Vol 25, No. 18S (June 20 Supplement), 2007: 45512007.

79. Jemal A, Siegel R, Ward E, Hao Y, Xu J, Thun MJ: Cancer statistics, 2009. CA Cancer J Clin 2009;59:225-249.

80. Van Cutsem E, Geboes K: The multidisciplinary management of gastrointestinal cancer. The integration of cytotoxics and biologicals in the treatment of metastatic colorectal cancer. Best Pract Res Clin Gastroenterol 2007;21:1089-1108.

81. Goldberg RM: Advances in the treatment of metastatic colorectal cancer. Oncologist 2005;10 Suppl 3:40-48.

82. Takahashi Y, Kitadai Y, Bucana CD, Cleary KR, Ellis LM: Expression of vascular endothelial growth factor and its receptor, KDR, correlates with vascularity, metastasis, and proliferation of human colon cancer. Cancer Res 1995;55:3964-3968.

83. Kim KJ, Li B, Winer J, Armanini M, Gillett N, Phillips HS, Ferrara N: Inhibition of vascular endothelial growth factorinduced angiogenesis suppresses tumour growth in vivo. Nature 1993;362:841-844.

84. Kabbinavar F, Hurwitz HI, Fehrenbacher L, Meropol NJ, Novotny WF, Lieberman G, Griffing S, Bergsland E: Phase II, randomized trial comparing bevacizumab plus fluorouracil (FU)/leucovorin (LV) with FU/LV alone in patients with metastatic colorectal cancer. J Clin Oncol 2003;21:60-65.

85. Kabbinavar FF, Schulz J, McCleod M, Patel T, Hamm JT, Hecht JR, Mass R, Perrou B, Nelson B, Novotny WF: Addition of bevacizumab to bolus fluorouracil and leucovorin in first-line metastatic colorectal cancer: results of a randomized phase II trial. J Clin Oncol 2005;23:36973705 .

86. Fuchs CS, Marshall J, Mitchell E, Wierzbicki R, Ganju V, Jeffery M, Schulz J, Richards D, Soufi-Mahjoubi R, Wang B, Barrueco J: Randomized, controlled trial of irinotecan plus infusional, bolus, or oral fluoropyrimidines in first-line treatment of metastatic colorectal cancer: results from the BICC-C Study. J Clin Oncol 2007;25:4779-4786.

87. Saltz LB, Clarke S, Diaz-Rubio E, Scheithauer W, Figer A, Wong R, Koski S, Lichinitser M, Yang TS, Rivera F, Couture F, Sirzen F, Cassidy J: Bevacizumab in combination with oxaliplatin-based chemotherapy as firstline therapy in metastatic colorectal cancer: a randomized phase III study. J Clin Oncol 2008;26:2013-2019.

88. Saltz L, Clarke S, Diaz-Rubio E, Scheithauer W, Figer A, Wong R, Koski S, Lichinitser M, Yang T, Cassidy $\mathrm{J}$ : Bevacizumab (Bev) in combination with XELOX or FOLFOX4: Updated efficacy results from XELOX-1/ NO16966, a randomized phase III trial in first-line metastatic colorectal cancer. Journal of Clinical Oncology 2007;ASCO Annual Meeting Proceedings Part I. Vol 25, No. 18S (June 20 Supplement): 4028

89. Giantonio BJ, Catalano PJ, Meropol NJ, O'Dwyer PJ, Mitchell EP, Alberts SR, Schwartz MA, Benson AB, 3rd:
Bevacizumab in combination with oxaliplatin, fluorouracil, and leucovorin (FOLFOX4) for previously treated metastatic colorectal cancer: results from the Eastern Cooperative Oncology Group Study E3200. J Clin Oncol 2007;25:1539-1544.

90. Wolmark N, Yothers G, O'Connell MJ, Sharif S, Atkins JN, Seay TE, Feherenbacher L, O'Reilly S, Allegra CJ: A phase III trial comparing mFOLFOX6 to mFOLFOX6 plus bevacizumab in stage II or III carcinoma of the colon: Results of NSABP Protocol C-08. J Clin Oncol 2009;27:18s, (suppl; abstr LBA4)

91. Hecht JR, Trarbach T, Jaeger E, Hainsworth J, Wolff R, Lloyd K, Bodoky G, Borner M, Laurent D, Jacques C: A randomized, double-blind, placebo-controlled, phase III study in patients (Pts) with metastatic adenocarcinoma of the colon or rectum receiving first-line chemotherapy with oxaliplatin/5-fluorouracil/leucovorin and PTK787/ ZK 222584 or placebo (CONFIRM-1). Journal of Clinical Oncology 2005;ASCO Annual Meeting Proceedings. Vol 23, No. 16S, Part I of II (June 1 Supplement): 3

92. Kohne C, Bajetta E, Lin E, Valle JW, Cutsem EV, Hecht JR, Moore M, Germond CJ, Meinhardt G, Jacques C: Final results of CONFIRM 2: A multinational, randomized, double-blind, phase III study in 2nd line patients (pts) with metastatic colorectal cancer (mCRC) receiving FOLFOX4 and PTK787/ZK 222584 (PTK/ZK) or placebo. Journal of Clinical Oncology 2007; ASCO Annual Meeting Proceedings Part I. Vol 25, No. 18S (June 20 Supplement): 4033

93. AstraZeneca: RECENTIN did not meet primary endpoint in Horizon III study in metastatic colorectal cancer. In, http:// astrazeneca.com/media/latest-press-releases/recoentinhorizon?itemId=8748245, 2010.

94. Grose R, Dickson C: Fibroblast growth factor signaling in tumorigenesis. Cytokine Growth Factor Rev 2005;16:179186.

95. Dirix LY, Vermeulen PB, Pawinski A, Prove A, Benoy I, De Pooter C, Martin M, Van Oosterom AT: Elevated levels of the angiogenic cytokines basic fibroblast growth factor and vascular endothelial growth factor in sera of cancer patients. Br J Cancer 1997;76:238-243.

96. Casanovas O, Hicklin DJ, Bergers G, Hanahan D: Drug resistance by evasion of antiangiogenic targeting of VEGF signaling in late-stage pancreatic islet tumors. Cancer Cell 2005;8:299-309.

97. Poon RT, Ng IO, Lau C, Yu WC, Fan ST, Wong J: Correlation of serum basic fibroblast growth factor levels with clinicopathologic features and postoperative recurrence in hepatocellular carcinoma. Am J Surg 2001;182:298-304.

98. Kunii K, Davis L, Gorenstein J, Hatch H, Yashiro M, Di Bacco A, Elbi C, Lutterbach B: FGFR2-amplified gastric cancer cell lines require FGFR2 and Erbb3 signaling for growth and survival. Cancer Res 2008;68:2340-2348.

99. Wong CI, Koh TS, Soo R, Hartono S, Thng CH, McKeegan E, Yong WP, Chen CS, Lee SC, Wong J, Lim R, Sukri 
N, Lim SE, Ong AB, Steinberg J, Gupta N, Pradhan R, Humerickhouse R, Goh BC: Phase I and biomarker study of ABT-869, a multiple receptor tyrosine kinase inhibitor, in patients with refractory solid malignancies. J Clin Oncol 2009;27:4718-4726.

100. Dai Y, Hartandi K, Ji Z, Ahmed AA, Albert DH, Bauch JL, Bouska JJ, Bousquet PF, Cunha GA, Glaser KB, Harris CM, Hickman D, Guo J, Li J, Marcotte PA, Marsh KC, Moskey MD, Martin RL, Olson AM, Osterling DJ, Pease LJ, Soni NB, Stewart KD, Stoll VS, Tapang P, Reuter DR, Davidsen SK, Michaelides MR: Discovery of N-(4-(3-amino1H-indazol-4-yl)phenyl)-N'-(2-fluoro-5-methylphenyl) urea (ABT-869), a 3-aminoindazole-based orally active multitargeted receptor tyrosine kinase inhibitor. J Med Chem 2007;50:1584-1597.

101. Albert DH, Tapang P, Magoc TJ, Pease LJ, Reuter DR, Wei RQ, Li J, Guo J, Bousquet PF, Ghoreishi-Haack NS, Wang B, Bukofzer GT, Wang YC, Stavropoulos JA, Hartandi K, Niquette AL, Soni N, Johnson EF, McCall JO, Bouska JJ, Luo Y, Donawho CK, Dai Y, Marcotte PA, Glaser KB, Michaelides MR, Davidsen SK: Preclinical activity of ABT-869, a multitargeted receptor tyrosine kinase inhibitor. Mol Cancer Ther 2006;5:995-1006.

102. Toh H, Chen P, Carr BI, Knox JJ, Gill S, Steinberg J, Carlson DM, Qian J, Qin Q, Yong W: A phase II study of ABT-869 in hepatocellular carcinoma (HCC): Interim analysis. J Clin Oncol 2009;27:15s, (suppl; abstr 4581)

103. Wedge SR, Ogilvie DJ, Dukes M, Kendrew J, Chester R, Jackson JA, Boffey SJ, Valentine PJ, Curwen JO, Musgrove HL, Graham GA, Hughes GD, Thomas AP, Stokes ES, Curry B, Richmond GH, Wadsworth PF, Bigley AL, Hennequin LF: ZD6474 inhibits vascular endothelial growth factor signaling, angiogenesis, and tumor growth following oral administration. Cancer Res 2002;62:46454655.

104. Carlomagno F, Vitagliano D, Guida T, Ciardiello F, Tortora G, Vecchio G, Ryan AJ, Fontanini G, Fusco A, Santoro M: ZD6474, an orally available inhibitor of KDR tyrosine kinase activity, efficiently blocks oncogenic RET kinases. Cancer Res 2002;62:7284-7290.

105. Heymach JV: ZD6474--clinical experience to date. Br J Cancer 2005;92 Suppl 1:S14-20.

106. Holden SN, Eckhardt SG, Basser R, de Boer R, Rischin D, Green M, Rosenthal MA, Wheeler C, Barge A, Hurwitz HI: Clinical evaluation of ZD6474, an orally active inhibitor of VEGF and EGF receptor signaling, in patients with solid, malignant tumors. Ann Oncol 2005;16:1391-1397.

107. Saunders MP, Wilson R, Peeters M, Smith R, Godwood A, Oliver S, Van Cutsem E: Vandetanib with FOLFIRI in patients with advanced colorectal adenocarcinoma: results from an open-label, multicentre Phase I study. Cancer Chemother Pharmacol 2009;64:665-672.

108. Michael M, Gibbs P, Smith R, Godwood A, Oliver S, Tebbutt N: Open-label phase I trial of vandetanib in combination with mFOLFOX6 in patients with advanced colorectal cancer. Invest New Drugs 2009;27:253-261.

109. Kim T, Saunders M, Salazar R, Guren T, Sorbye H, Samuel L, Sanders N, Pover G, Im S: A randomized, doubleblind, placebo-controlled phase II study of vandetanib plus FOLFIRI in patients with advanced colorectal cancer (CRC). Print this page In 2009 Gastrointestinal Cancers Symposium 2009.

110. Nallapareddy S, Eckhardt SG, O’Bryant CL, Eppers S, Diab S, Kane MA, Weekes CD, Spratlin JL, Messersmith WA, Leong S: A phase I study of gemcitabine, capecitabine, and vandetanib in patients with advanced solid tumors with an expanded cohort in biliary and pancreatic malignancies. J Clin Oncol 2010;28:15s (suppl; abstr 2535)

111. Arao T, Yanagihara K, Takigahira M, Takeda M, Koizumi F, Shiratori Y, Nishio K: ZD6474 inhibits tumor growth and intraperitoneal dissemination in a highly metastatic orthotopic gastric cancer model. Int J Cancer 2006; 118:483489.

112. McCarty MF, Wey J, Stoeltzing O, Liu W, Fan F, Bucana C, Mansfield PF, Ryan AJ, Ellis LM: ZD6474, a vascular endothelial growth factor receptor tyrosine kinase inhibitor with additional activity against epidermal growth factor receptor tyrosine kinase, inhibits orthotopic growth and angiogenesis of gastric cancer. Mol Cancer Ther 2004;3:1041-1048.

113. Lu D, Jimenez X, Zhang H, Bohlen P, Witte L, Zhu Z: Selection of high affinity human neutralizing antibodies to VEGFR2 from a large antibody phage display library for antiangiogenesis therapy. Int J Cancer 2002;97:393-399.

114. Spratlin JL, Cohen RB, Eadens M, Gore L, Camidge DR, Diab S, Leong S, O'Bryant C, Chow LQ, Serkova NJ, Meropol NJ, Lewis NL, Chiorean EG, Fox F, Youssoufian H, Rowinsky EK, Eckhardt SG: Phase I pharmacologic and biologic study of ramucirumab (IMC-1121B), a fully human immunoglobulin G1 monoclonal antibody targeting the vascular endothelial growth factor receptor-2. J Clin Oncol;28:780-787.

115. Chiorean E, Sweeney C, Hurwitz H, Savage S, Cohen R, Schwartz J, Wang G, Fox F, Rowinsky EK, Youssoufian $\mathrm{H}$ : Phase I dose-escalation study of the anti-VEGFR-1 recombinant human IgG1 MAb IMC-1121B administered every other weeks (q2W) or every $3(\mathrm{q} 3 \mathrm{w})$ in patients (pts) with advanced cancers. Molecular Targets and Cancer Therapeutics 2007; Conference Proceedings Abstract B15.

116. Spratlin JL, Mulder KE, Mackey JR: Ramucirumab (IMC1121B): a novel attack on angiogenesis. Future Oncol 2010;6:1085-1094.

117. Zhu AX, Finn RS, Mulcahy MF, Gurtler JS, Sun W, Schwartz JD, Rojas P, Dontabhaktuni A, Youssoufian H, Stuart KE: A phase II study of ramucirumab as first-line monotherapy in patients (pts) with advanced hepatocellular carcinoma (HCC). J Clin Oncol 2010;28:15s, 2010 (suppl; abstr 4083)

118. Wu Y, Zhong Z, Huber J, Bassi R, Finnerty B, Corcoran E, Li H, Navarro E, Balderes P, Jimenez X, Koo H, 
Mangalampalli VR, Ludwig DL, Tonra JR, Hicklin DJ: Anti-vascular endothelial growth factor receptor-1 antagonist antibody as a therapeutic agent for cancer. Clin Cancer Res 2006;12:6573-6584.

119. Krishnamurthi SS, LoRusso PM, Goncalves PH, Fox F, Rowinsky EK, Schwartz J, Youssoufian H: Phase 1 study of weekly anti-vascular endothelial growth factor receptor-1 (VEGFR-1) monoclonal antibody IMC-18F1 in patients with advanced solid malignancies. J Clin Oncol 2008;26: (May 20 suppl; abstr 14630).

120. Lockhart AC, Rothenberg ML, Dupont J, Cooper W, Chevalier P, Sternas L, Buzenet G, Koehler E, Sosman JA, Schwartz LH, Gultekin DH, Koutcher JA, Donnelly EF, Andal R, Dancy I, Spriggs DR, Tew WP: Phase I study of intravenous vascular endothelial growth factor trap, aflibercept, in patients with advanced solid tumors. J Clin Oncol;28:207-214.

121. Tew WP, Gordon M, Murren J, Dupont J, Pezzulli S, Aghajanian C, Sabbatini P, Mendelson D, Schwartz L, Gettinger S, Psyrri A, Cedarbaum JM, Spriggs DR: Phase 1 study of aflibercept administered subcutaneously to patients with advanced solid tumors. Clin Cancer Res 2010;16:358366.

122. Holash J, Davis S, Papadopoulos N, Croll SD, Ho L, Russell M, Boland P, Leidich R, Hylton D, Burova E, Ioffe E, Huang T, Radziejewski C, Bailey K, Fandl JP, Daly T, Wiegand SJ, Yancopoulos GD, Rudge JS: VEGF-Trap: a VEGF blocker with potent antitumor effects. Proc Natl Acad Sci U S A 2002;99:11393-11398.

123. Cursiefen C, Chen L, Borges LP, Jackson D, Cao J, Radziejewski C, D'Amore PA, Dana MR, Wiegand SJ, Streilein JW: VEGF-A stimulates lymphangiogenesis and hemangiogenesis in inflammatory neovascularization via macrophage recruitment. J Clin Invest 2004;113:10401050.

124. Tang P, Cohen SJ, Bjarnason GA, Kollmannsberger C, Virik K, MacKenzie MJ, Brown J, Wang L, Chen AP, Moore MJ: Phase II trial of aflibercept (VEGF Trap) in previously treated patients with metastatic colorectal cancer (MCRC): A PMH phase II consortium trial. J Clin Oncol 2008;26: May 20 suppl; abstr 4027.

125. Olive KP, Jacobetz MA, Davidson CJ, Gopinathan A, McIntyre D, Honess D, Madhu B, Goldgraben MA, Caldwell ME, Allard D, Frese KK, Denicola G, Feig C, Combs C, Winter SP, Ireland-Zecchini H, Reichelt S, Howat WJ, Chang A, Dhara M, Wang L, Ruckert F, Grutzmann R, Pilarsky C, Izeradjene K, Hingorani SR, Huang P, Davies SE, Plunkett W, Egorin M, Hruban RH, Whitebread N, McGovern K, Adams J, Iacobuzio-Donahue C, Griffiths J, Tuveson DA: Inhibition of Hedgehog signaling enhances delivery of chemotherapy in a mouse model of pancreatic cancer. Science 2009;324:1457-1461. 